\title{
O niesłusznej niechęci Zdziechowskiego do Nietzschego
}

Analizując poglądy filozoficzne Mariana Ursyna Zdziechowskiego, może czytelnik zauważyć rzecz nietypową, wręcz zadziwiającą $\mathrm{w}$ postawie osoby takiego formatu. Mówimy w końcu o wybitnym profesorze literatury powszechnej, profesorze czterech uniwersytetów ${ }^{1}$, późniejszym rektorze Uniwersytetu Wileńskiego. Zadziwia więc fakt, że często potrafił wileński profesor ignorować nielubianych przez siebie filozofów, czy działaczy społeczno-politycznych. Ignorancja takowa przejawia się w tym, że krytykując na przykład idee bolszewizmu, które miały infekować społeczeństwo II Rzeczypospolitej, nie stara się filozof prowadzić polemiki z żadnym pisarzem tego nurtu. Działanie takie ma zapewne źródło w mistycznym rysie jego filozofii, traktującym zło jako istniejące w świecie immanentnie, tkwiące w nim tak długo, jak długo po ziemi stąpać będzie człowiek. Bolszewizm, pojmowany jako jawny przykład materializującego się zła, był więc przez pisarza oceniany skrajnie negatywnie, nie zawierał $\mathrm{w}$ sobie żadnych pozytywnych wartości i wymagał od nas chrześcijańskiego heroizmu, koniecznego do po-

\footnotetext{
${ }^{1}$ Zdziechowski był profesorem czterech uniwersytetów: Jagiellońskiego, Wileńskiego - a nominalnie - Warszawskiego i Londyńskiego. Zob. Z. Chocimski, Przedmowa, [w:] M. Zdziechowski, Widmo przyszłości, Stowarzyszenie Kulturalne Fronda, Warszawa 1999, s. 5.
} 
radzenia sobie z tym „wtrąceniem się ciemnych potęg z państwa ciemności"2. O ile wyjaśnienie (nie zaś usprawiedliwienie) tego typu daje się jeszcze zrozumieć w odniesieniu do nurtów ocenianych z perspektywy jego stanowiska jako totalnie bezwartościowe, niegodne nawet polemiki, o tyle przynajmniej zdziwienie budzi fakt ignorowania przez niego myślicieli, których twórczość mogłaby być cenną inspiracją dla jego rozważań.

Przykładem znamiennym jest tutaj filozofia Fryderyka Wilhelma Nietzschego. Wielokrotnie znajdujemy $\mathrm{w}$ pismach wileńskiego profesora nawiązanie do nietzscheańskiej terminologii, zawsze jednak są to nawiązania rzucane mimochodem, często bez wymienienia nawet nazwiska ich twórcy. Dowodem jawnej niechęci są jego słowa, iż początkowo zignorował dorobek Jana Karola Kochanowskiego, bo pobieżna lektura jego pism wydawała się nietzscheańskim, „posępnym materializmem zmierzającym ku apoteozie brutalności”3. Tak jednostronna ocena myśli Nietzschego musi się wydawać krzywdząca i niesprawiedliwa. Co najmniej kilka spostrzeżeń niemieckiego filozofa mógłby polski myśliciel uznać za wartościowe, gdyby tylko z miejsca nie zanegował wartości jego myśli. Spróbuję uzasadnić powyższą tezę na kilku przykładach.

Potępienie militaryzmu i nacjonalizmu niemieckiego. Filozofię niemiecką badał Zdziechowski z kilku co najmniej powodów. $\mathrm{Na}$ pewno ze względu na koncepcje niemieckich myślicieli, którzy propagowali potrzebę zmazania win rozbiorów, odbudowy państwa polskiego $\mathrm{z}$ wybranym przez nas królem i potrzebę federacji państw niemieckich, austrowęgierskich i polskiego, którego wschodnią granicę trzeba przesuwać coraz bardziej w gąb Rosji. Erzberg, Frantz, Neuman są tu najbardziej reprezentatywni. Ale był też inny, znacznie ważniejszy powód, mianowicie chęć zrozumienia imperializmu i militaryzmu typowego dla państw wieku XIX i XX, który w Niemczech przyjął specyficzny charakter. Kluczem do zrozumienia takiego stanu rzeczy była analiza niemieckiej myśli filozoficznej.

Nie będzie zbytnim uproszczeniem stwierdzenie, że Zdziechowski widział w niemieckiej filozofii pewną tendencję zapoczątkowaną przez Kanta, rozwijaną przez innych idealistów z Heglem na czele, której rozwój kończy się na Schopenhauerze i Nietzschem. Istota tej tendencji streszcza się idei kultu pań-

${ }^{2}$ M. Zdziechowski, Duchowa podstawa walki z bolszewizmem, [w:] tenże, Wybór pism, Znak, Kraków 1993, s. 523.

${ }^{3}$ M. Zdziechowski, J. K. Kochanowski, [w:] tenże, Europa, Rosja, Azja. Szkice polityczno-literackie, Antyk, Komorów 2007, s. 37-38.

${ }^{4}$ Zob. rozprawę Fr. W. Föster, [w:] tenże, Europa, Rosja, Azja. 
stwa i gotowości poświęcenia mu wszystkiego, życia każdej jednostki, a także podporządkowania moralności interesowi państwa ${ }^{5}$. Ale obok niemieckiego idealizmu rozwijał się także romantyczny irracjonalizm, których połączenie sprawiło, że Niemcy to naród „hiperboliczny. Nieustannie przez żywiołową, rozpasaną energię porywany ku przedsięwzięciom, które i rozum, i moralność, i religia zgodnie potępiają"6. Nietzsche miał więc w opinii polskiego filozofa wpisywać się w rozwój takiego stanowiska, przypieczętować narodziny takiej postawy dzięki swojemu immoralizmowi, rzekomemu kultowi brutalności i potępieniu jedynie słusznej moralności - etyki chrześcijańskiej.

Zaznajomienie się zaś z jego biografią odsłoniłoby przed Zdziechowskim pewien istotny fakt, mianowicie, że kult siły, idea nadczłowieka łamiącego wszystkie swoje ograniczenia i słabości stworzona została - jak zauważa Żelazny - przez człowieka chorego, w którym „pręgierz ascetycznego moralizmu" pogłębiał tylko depresję i poczucie stłamszenia. Oczywiście nie można przez to dyskredytować wartości filozofii niemieckiego myśliciela, ale też z drugiej strony nie ulega wątpliwości, że Zdziechowski, autor książeczki O okrucieństwie, wrażliwy na ludzkie krzywdy i niedole, zawsze pierwszy potępiający bestializm i okrucieństwo, z pewnością znalazłby w sobie wolę zrozumienia tragicznego losu Nietzschego.

Zwróćmy jednak uwagę na inny, mniej oczywisty fakt, który już wymagać będzie dokładnej argumentacji. Chodzi o to, że sam Nietzsche potępiał własny naród dokładnie za to samo, za co potępiał go Zdziechowski. Niemiecki filozof obserwował zjednoczenie własnego państwa, jego drogę do potęgi militarnej i gospodarczej. Początkowo jako entuzjasta Wagnera musiał być przychylny idei zjednoczenia Rzeszy, gotów iść za nią na front ${ }^{8}$. Pojawiło się jednak zwątpienie, a później nawet przekonanie o tym, że wzrost siły państwa zawsze odbywa się kosztem upadku kultury, czyli tego, co w każdym państwie najważniejsze. Wszystkie sfery życia społecznego, niestety także szkolnictwo, zostają podporządkowane interesowi państwa. Kultura ubożeje i upada, bo „zawdzięcza największe dzieła okresom politycznej słabości”".

${ }^{5}$ Tamże, s. 89.

${ }^{6}$ M. Zdziechowski, Mickiewicz, Mereżkowski i rewolucja rosyjska, [w:] tenże, Wybór pism, s. 221.

${ }^{7}$ M. Żelazny, Nietzsche, „ten wielki wzgardziciel”, WN UMK, Toruń 2007, s. 197.

${ }^{8}$ Ze względu na wątły stan zdrowia służył jako sanitariusz. Zob. T. Gomez, Fryderyk Nietzsche, tłum. T. Ostrowski, Muza S.A., Warszawa 2007, s. 44.

${ }^{9}$ F. Nietzsche, Ludzkie, arcyludzkie, tłum. K. Drzewiecki, Zielona Sowa, Kraków 2006, par. 465. 
Z tej perspektywy niemiecki pangermanizm jest dla Nietzschego ideą zgubną, tak samo zresztą jak w ujęciu Zdziechowskiego. Mógłby polski myśliciel nawiązać do swojej wizji całkowitego upadku kultury, który wieszczył, wizji katastrofy, która zetrze w pył całą kulturę, po której nic już nie pozostanie ${ }^{10}$.

Nietzsche pogardzał własnymi rodakami, bo swoim poziomem wykształcenia mogli się jeszcze parę dekad temu szczycić, a dziś traktują go jak chorobę ${ }^{11}$. Szkoła okazuje się w najwyższej mierze przydatna swojemu państwu, bo przestała uczyć sztuki myślenia. Jak poetycko wydrwił Nietzsche: „Niemiec nie ma palców do chwytania niuansów..." ${ }^{2}$.

Militaryzacja życia społecznego sięga jednak dalej. Mamy bowiem do czynienia $\mathrm{z}$ narodem, który nawet mówi jak wojskowi, a „obrzydliwszych dźwięków szukać w Europie próżno"13. Poczucie katastrofy towarzyszyło niemieckiemu myślicielowi. Widział, że już w jego czasach żołnierzowi w mundurze schodziło się $\mathrm{z}$ drogi, a przed oficerem ściągano kapelusz ${ }^{14}$. Uzależnianie muzyki i sztuki od państwa to kolejny krok do upadku kultury, a nawet, jak pokaże historia, także narodu. Nietzsche zresztą przepowiedział, że nadchodzące stulecie będzie stuleciem wojen. Trudno mu było patrzeć na to, co się dzieje i mając w pamięci przykład Napoleona dochodzi do wniosku, że wchodzimy w nowy okres, okres wojen tak straszliwych, jakich świat jeszcze nie widział $^{15}$. Bonaparte przecież pokazał, jak prowadzić wojny z całym światem.

Ponadto człowiek współczesny zbyt się rozpasał, by żyć w swoim sterylnym, bezpiecznym świecie. Rozważał Nietzsche ogólną kondycje ludzką i dochodził do wniosku, że ludzie jemu współcześni nie tylko tęsknią za wojną, ale nawet śnią o wojnach tak straszliwych, jakich jeszcze nie było ${ }^{16}$. Niemcy są tu najbardziej reprezentatywni, a wszystko przez to, o czym pisać będzie Zdziechowski - przez posłuszeństwo i karność tego narodu. Żyjemy w czasach śmierci Boga, a jego normy funkcjonują już tylko siłą rozpędu, więc Niemiec w końcu zrozumie, że ponad nim nikt już nie stoi i odkryje drzemiące w sobie pokłady wielkiej energii, o które wcześniej siebie nie podejrzewał ${ }^{17}$.

${ }^{10}$ M. N. Jakubowski, Ciagłość historii i historia ciagłości. Polska filozofia dziejów, UMK, Toruń 2004, s. 232.

${ }^{11}$ F. Nietzsche, Jutrzenka, tłum. L. M. Kalinowski, Zielona Sowa, Kraków 2006, par. 190.

${ }^{12}$ F. Nietzsche, Zmierzch bożyszcz, tłum. P. Pieniążek, Zielona Sowa, Kraków 2004, s. 50.

${ }^{13}$ F. Nietzsche, Wiedza radosna, tłum. L. Staff, Zielona Sowa, Kraków 2006, par. 104.

${ }^{14}$ T. Kotłowski, Niemcy, dzieje państwa i społeczeństwa 1890-1945, Avalon, Kraków 2008.

${ }^{15}$ F. Nietzsche, Wiedza radosna, par. 362.

${ }^{16}$ F. Nietzsche, Ludzkie, arcyludzkie, par. 477.

${ }^{17}$ F. Nietzsche, Jutrzenka, przeł. L. M. Kalinowski, Zielona Sowa, Kraków 2006, par. 207. 
Tego samego obawiał się Zdziechowski, wyczuwał niepokoje i dążenia, które doprowadziły do wojny światowej, a zaraz po jej zakończeniu pisał „wszyscy czujemy nową wojnę w powietrzu”18. Przyczynę kryzysu kultury widział w upadku chrześcijańskiej moralności. Będzie to tematem jednego z kolejnych punktów, tutaj jednak zwróćmy uwagę na pewną różnicę w podejściu obu filozofów związaną z odmiennością czasów, w jakich przyszło im żyć. Obserwując Niemcy epoki Bismarcka, Nietzsche wieszczy nadejście ciężkich czasów, niszczycielskich i niebezpiecznych, co każe mu tym dosadniej krytykować własny naród. Zdziechowski natomiast jest jak najlepszego zdania o Niemcach, widząc w nich jedynie przejaw tego, co infekuje myśl społeczną większości narodów na kontynencie, czyli imperializmu i militaryzmu. Najstraszniejszym skutkiem wojny światowej były dla polskiego filozofa narodziny bolszewizmu w Rosji. To w komunizmie (utożsamiał te dwa pojęcia) widział niebezpieczeństwo grożące całej naszej kulturze, czystą siłę destrukcyjną, negację wszelkiego istnienia. Internacjonalizm bolszewicki podziałał jak katalizator dla nacjonalizmu państw zachodnich, chcących bronić się przed tą ideologią, a tym samym, tworząc lekarstwo tak samo niebezpieczne, jak choroba. Nacjonalizm powojenny zaczął przyjmować wszystkie metody stosowane przez internacjonalizm ${ }^{19}$, co zauważał Zdziechowski już na początku lat dwudziestych. Wieszczył ich zwarcie na długo przed drugą wojną światową i obserwował przez kolejne lata, jak eskalacja konfliktu między nimi przybiera na sile, by w 1934 roku napisać, że ich starcie z płaszczyzny ideologicznej przeszło na polityczną, ekonomiczną i „weszło aż w głębię dusz ${ }^{20 ”}$, zaś wyścig między „hitleryzmem a komunizmem” wszedł w ostatnią fazę, ten pierwszy „wyprzedził współzawodników swoich o dni kilka, może nawet godzin kilka ${ }^{21}$ ". Modlił się Zdziechowski, by wieszczonej przez siebie wojny nie dożyć i tak też się stało.

Rodzi się pytanie, na ile Zdziechowski uważał Nietzschego za odpowiedzialnego za taki stan rzeczy? Widzimy jedynie, że był dla niego jednym z kolejnych myślicieli rozwijających nacjonalizm niemiecki, natomiast nie wiemy, czy (i na ile) wileński profesor obarcza go winą za powstanie nazizmu. Dziś już nie postrzega się Nietzschego jako twórcę czy ducha przewodniego narodowego socjalizmu niemieckiego, a Mirosław Żelazny, bodaj jako pierwszy

\footnotetext{
${ }^{18}$ Słowa te padły w roku 1923. M. Zdziechowski, Idea polska na kresach, [w:] tenże, Widmo przyszłości, Stowarzyszenie Kulturalne Fronda, Warszawa 1999, s. 17.

${ }^{19}$ M. Zdziechowski, Tragiczna Europa, s. 457.

${ }^{20}$ Tamże.

${ }^{21}$ Tamże, s. 458.
} 
polski badacz ${ }^{22}$, wskazuje na bezpodstawność takich interpretacji. Jednak Zdziechowski, który zmarł dopiero w roku 1938 i widział rozwój nazizmu, którego to tak się obawiał, mógł mieć o niemieckim koledze po fachu odmienne zdanie. Czy tak właściwie było, czy może w ogóle wileński profesor nie rozważał nietzscheanizmu nawet $\mathrm{w}$ tym kontekście - tego nie wiemy.

Pesymizm jako punkt wyj ścia. Pesymizmobjawia się w pismach Mariana Zdziechowskiego w każdej sferze, jakiej filozof poświęca uwagę. Wiąże się to zapewne z jego poglądem na temat zła, które immanentnie tkwi w świecie, musi być zatem obecne wszędzie tam, gdzie mówimy o działalności ludzkiej. Sam ostentacyjnie wręcz przyznawał się do niego, mówiąc: „Zarzucają mi pesymizm. I przejawiam go istotnie, tak w filozofii, jak w sprawach politycznych i życia praktycznego. Ale pesymizm nie jest bezsilnym załamywaniem rąk ${ }^{23}$ ". Ostatnie ze zdań tego cytatu doskonale wskazuje kolejny wątek, który koresponduje z filozofią nietzscheańską, mianowicie gruntowne rozdzielenie pesymizmu od nihilizmu. Teza o degeneracji moralnej ludzkości i wynikający z niej dystans człowieka musi prowadzić nie do pasywnego przyglądania się tej tendencji, której jak mogłoby się zdawać, nie da się powstrzymać, lecz do czynnego aktu chrześcijańskiego heroizmu. O potrzebie czynu tego rodzaju powiemy w kolejnym punkcie, tutaj zaś skupmy się na samym pesymizmie.

Należałoby go nazwać pesymizmem afirmatywnym, gdyż pisma filozofa przenika żar i gorący sprzeciw wobec zła. Wiara wymusza na nas heroizm, który przeciwstawia się złu w każdej sytuacji i wbrew wszystkiemu, contra spem spero ${ }^{24}$. Gdy Jakubowski powie o pesymizmie jawiącym się w dziele O okrucieństwie, że "ma charakter aktywistyczny czy wręcz heroiczny ${ }^{25}$ ", to stwierdzenie tego typu określa w zasadzie całą filozofię wileńskiego profesora.

Trudno też nie zgodzić się z analizą Marciniak, gdy stwierdza ona, że aktywistyczna postawa wynika $\mathrm{z}$ fascynacji Zdziechowskiego myślą Schopenhauera. Autorka dostrzega pewną słuszność w staraniach różnych badaczy, którzy odmawiają uznania schopenhaueryzmu za pesymizm. „Dla świadomego nieszczęsnej swej sytuacji człowieka filozof [Schopenhauer - przyp. M. P.] widzi bowiem nadzieję. Interpretacje te Zdziechowski znał i sam o nich wie-

${ }^{22}$ Zob. Rozdział $W$ bagnie narodowego socjalizmu (w cytowanym wydaniu Nietzsche, „ten wielki wzgardziciel”), gdzie Żelazny jako pierwszy polski badacz wykazuje, że nietzscheanizm nie ma nic wspólnego $\mathrm{z}$ bełkotem nazistowskim.

${ }^{23}$ M. Zdziechowski, Idea polska na kresach, s. 20.

${ }^{24}$ M. Zaczyński, Wstęp, [w:] M. Zdziechowski, Wybór pism, s. 9.

${ }^{25}$ M. N. Jakubowski, Ciagłłość historii, s. 221. 
lokrotnie wspomina, jak się wydaje, $\mathrm{z}$ aprobatąą". Zdziechowski szukał jakiejś nadziei wbrew własnemu pesymizmowi, wskazywał inne możliwości uchronienia nas przed zbliżającą się katastrofą, a jak sam uważał, po prostu trzeźwo oceniał rzeczywistośćc ${ }^{27}$. Miała Marciniak słuszność wskazując, że Zdziechowski, autor obszernej, dwutomowej pracy dotyczącej pesymizmu, cenił Schopenhauera i zgadzał się z jego koncepcją, przeciwstawiając się jedynie postawie bierności, jaka samorzutnie miała się pojawiać po lekturze Świata jako woli i przedstawienia ${ }^{28}$. Zdaje się jednak, że gdyby zgodzić się ze Zdziechowskim, że Schopenhauer żadnym pesymistą nie był, że wskazywał pewne konkretne rozwiązania dotyczące absurdu ludzkiej egzystencji, to $\mathrm{z}$ tego samego powodu sam Zdziechowski nie miałby podstaw do tego, by uznawać się za pesymistę.

Przezwyciężenie pesymizmu, jak i fascynacja Schopenhauerem nieobce były też Nietzschemu. Jeszcze w młodym okresie swej działalności pisarskiej poświęcił mu filozof pochwalną rozprawę Schopenhauer jako wychowawca $i$ pisarz ${ }^{29}$, fascynacja jego myślą trwała zaś tak długo, jak fascynacja Wagnerem. Zdumiewać więc może słuszny wniosek Żelaznego, że Schopenhauer, jakim go widział młody Nietzsche, nigdy nie istniał ${ }^{30}$. On narodził się dopiero podczas rozmów u Wagnerów, a młodszy z filozofów znał starszego jedynie poprzez pryzmat jego dzieł. Nie zmienia to jednak faktu, że dostrzegał konieczność rozprawienia się z pesymizmem.

W tym celu wprowadził Nietzsche koncepcje amor fati, umiłowania losu. Jak tłumaczył, los swój trzeba pokochać, szukać sposobów jego zmiany i poprawienia, ale nie odrzucać go i nie odwracać się od niego ${ }^{31}$. Pozostanie wiernym ziemi było tutaj buntem przeciw chrześcijańskiej ascezie i szkodliwej, zdaniem filozofa, wierze, że życie nasze jest jedynie wstępem do jakiegoś nadświatowego stanu metafizycznego.

${ }^{26}$ M. Marciniak, Inspiracje Schopenhauerowskie w filozofii zła Mariana Zdziechowskiego, „Studia z Historii Filozofii”, 1(4)/2013, s. 123.

${ }^{27}$ M. Zdziechowski, Ze wspomnień o Piłsudzkim i jego epoce, [w:] tenże, Widmo przyszłości, s. 124.

${ }^{28}$ M. Marciniak, Inspiracje, s. 126.

${ }^{29}$ F. Nietzsche, Niewczesne rozważania, tłum. L. Staff, Zielona Sowa, Kraków 2003.

${ }^{30}$ M. Żelazny, Wpływ Schopenhauera $i$ Wagnera na twórczość młodego Nietzschego, „Studia Filozoficzne", nr 9 (180), 1981, s. 65-84.

${ }^{31}$ F. Nietzsche, Ecce Homo, tłum. L. Staff, Zielona Sowa, Kraków 2003, s. 32. 
Jak wskazała Marciniak, Zdziechowski cenił myśl Schopenhauera także za jego buddyjską afirmację życia ${ }^{32}$. Sam chciał przy tym połączyć ją z radosną wiarą w Boga, co byłoby pewnym krokiem na drodze do przemiany Kościoła, przezwyciężenia jego stagnacji i otworzenia na potrzeby nowej epoki. Oczywiście nietzscheańskie umiłowanie losu było czymś wierze chrześcijańskiej przeciwnym, różnice te zaś wynikają z innego podejścia myślicieli do roli Kościoła i diametralnie różnych odpowiedzi na pytanie o to, na czym polega jego rola.

Podobieństwa w krytyce Kościoła. Zdziechowski ze względu na swoje poglądy jest dziś zaliczany do nurtu modernizmu katolickiego. Jego walka nie była walką z Kościołem, lecz o Kościół ${ }^{33}$, co sprawiało, że nie wahał się dokonywać jego dogłębnej krytyki. Także analiza tej bliskiej mu instytucji przeszyta jest pesymizmem, bo zdawał się nie dowierzać własnym receptom. Podstawowym błędem kościoła był jego klerykalizm, który polega na „utożsamieniu interesów Kościoła, który jest Ciałem Chrystusa, z interesem osobistym hierarchii ${ }^{34}$. Idąc tą drogą, począł Kościół obrastać w dogmaty i służyć jedynie własnym, niegodziwym celom, czego ostatnim etapem było przyjęcie dogmatu o nieomylności papieża. Przez to postawił się w sytuacji bez wyjścia, przestał odpowiadać na potrzeby człowieka, sprzeniewierzył się własnej etyce, która miała wznosić człowieka na wyżyny moralne, bo „w kim zmysłu religijnego nie ma, ten jest kaleką ${ }^{35}$. Dbanie jedynie o partykularny interes hierarchów, a przede wszystkim o sprawowanie i umacnianie władzy są jednak niczym w porównaniu z wielosetletnią historią kościelnych zbrodni, czego najlepszą egzemplifikacją jest książeczka O okrucieństwie, w której opisuje autor krwawe praktyki kleru, nazywając je nawet w pewnym momencie satanizmem ${ }^{36}$.

Krytyka Zdziechowskiego, wsparta bezkompromisową niezgodą na szerzące się zło, jest dosadna i dogłębna. Musi taką być, bo w sytuacji zbliżającej się nieuchronnie katastrofy nie pozostaje nam nic innego, jak powrót do tych wartości, które w średniowieczu scalały Europę i wpływały zbawiennie na stosunki międzyludzkie. Kościół musi zmienić swe oblicze, otworzyć się na intelektualistów i na młodzież, stać się znowu żywym ciałem Chrystusa,

\footnotetext{
${ }^{32}$ M. Marciniak, Inspiracje, s. 124.

${ }_{33}$ M. Zaczyński, Rozdźwięk okropny w pięknie świata, [w:] M. Zdziechowski O okrucieństwie, Znak, Kraków 1993, s. 67.

${ }^{34}$ M. Zdziechowski, Zadania katolicyzmu w chwili obecnej, [w:] tenże, Wybór pism, s. 107.

${ }^{35}$ M. Zdziechowski, Kościół a inteligencja, [w:] tenże, Wybór pism, s. 161.

${ }^{36}$ M. Zdziechowski, O okrucieństwie, s. 22.
} 
by mógł zjednoczyć wszystkich wyznawców. To stąd uwielbienie filozofa dla działalności Andrzeja Towiańskiego, emigracyjnego mesjanisty, który występował przeciw skostniałości Urzędu, przeciw hierarchii kościelnej i zniewoleniu sumień, potępiał jednostronność ideału ascetycznego, a za wzór życia brał Chrystusa ${ }^{37}$. Nie zważał przy tym Zdziechowski na fakt, znany w literaturze przedmiotu, że Towiański począł w swoim Kole Sług Sprawy Bożej czynić te same błędy, które wytykał Kościołowi ${ }^{38}$. Zdaje się, że bardziej chodziło mu o doniosłość treści jego pism.

Zdawać by się mogło, że na tej płaszczyźnie Zdziechowski nie mógłby znaleźć w nietzscheanizmie niczego wartościowego. W końcu jego krytyka służyć miała, po pierwsze, przemienieniu oblicza Kościoła, po drugie zaś uzmysłowienie w każdym wyznawcy potrzeby heroicznego czynu, czynu wbrew wszystkiemu, contra spem spero, bo w dniu dzisiejszym święcą triumf idee, które oderwały człowieka od Boga, które nakazują człowiekowi uważać się za Boga, czego najlepszym przykładem jest dla Zdziechowskiego nietzscheański Zaratustra $^{39}$.

Ale to właśnie krytyka instytucji Kościoła jest tym, co łączy koncepcje obu filozofów, a fakt, że obaj dokonują jej w innym celu, wcale nie zmienia tego stanu rzeczy. Nietzsche z radością analizował zmierzch religii chrześcijańskiej wraz z jej moralnością, Zdziechowski z poczuciem goryczy i własnej bezsilności wyciągał konkluzje o skostniałości instytucji, która winna zrzeszać w pokoju całą ludzkość, ale ich diagnozy były tego samego rodzaju, a dzięki ich zestawieniu widać wiele istotnych podobieństw między nimi. Spróbujmy wynotować najważniejsze.

Motyw śmierci Boga pojawia się $\mathrm{w}$ pismach niemieckiego filozofa stosunkowo wcześnie ${ }^{40}$, a jego sztandarowe hasło „Bóg umarl” (czy tłumacząc dokładniej za Żelaznym: „Bóg jest martwy” ${ }^{41}$ ), mówi nam nie o tym, że nadeszła śmierć najwyższej istoty w teologii chrześcijańskiej, lecz że normy głoszone przez chrześcijaństwo zostały przejrzane; wyszła na jaw ich nietrafność i śmieszność. Niechęć Nietzschego do wszelkiej metafizyki sprawia, że jego poetycki opis śmierci Boga winniśmy rozumieć na płaszczyźnie etycznej.

\footnotetext{
${ }^{37}$ M. Zdziechowski, Wezwanie do świętości, [w:] tenże, Wybór pism, s. 152 i n.

${ }^{38}$ Szerzej na ten temat w: A. Sikora, Towiański: rewelacja i spetnienie, [w:] tenże, Posłannicy słowa. Hoene-Wroński, Towiański, Mickiewicz, PWN, Warszawa 1967.

${ }^{39}$ M. Zdziechowski, Wezwanie do świętości, s. 113.

${ }^{40}$ Zob. słynny 125. aforyzm Wiedzy radosnej, zatytułowany Człowiek oszalały.

${ }^{41}$ O poprawności przekładu sztandarowego hasła Nietzschego zobacz: M. Żelazny, Nietzsche, s. 125.
} 
Bóg tworzący świat był młodym i płodnym twórcą, by potem stać się ojcem o ciężkiej ręce dla narodu wybranego ${ }^{42}$. Z czasem jednak jego oblicze ewoluuje, a wraz z rozprzestrzenianiem się chrześcijaństwa zdaje się Bóg starzeć, przestaje być zdolnym do karania nas za grzechy od razu. Stan kapłański, dążący do władzy i wzmocnienia swojej pozycji bierze na siebie rolę tłumacza boskiej woli, strasząc nas karą w życiu wiecznym. Starzejący się Bóg jest w stanie jedynie wypisywać nam „weksle”, które zrealizuje na „tamtym świecie $^{43}$ ". Gdy zaś stary Bóg umrze, Zaratustra tańczyć będzie radośnie na wieść o tym.

Ta epicka przenośnia doskonale obrazuje zarówno upadek chrześcijańskiej moralności, jak i niebezpieczną postawę kleru, które diagnozował Zdziechowski, a w efekcie stwierdzał, że historia chrześcijaństwa to ,jedno wielkie, olbrzymie fiasco ${ }^{44}$ ". Ale nie jest to podobieństwo jedyne. Przyjęcie Chrystusa za wzór postępowania, do którego nawoływał Towiański, a czego sami hierarchowie nie robią od dawna, koresponduje ze stwierdzeniem Nietzschego, że w historii pojawił się tylko jeden chrześcijanin, ten, który umarł na krzyżu ${ }^{45}$. Poszukiwanie pozytywnych pierwiastków w buddyzmie, które prowadził Zdziechowski, obecne jest w miejscach, gdzie Nietzsche zestawia wielką religię wschodu z chrześcijaństwem. Wspomnijmy w końcu, że sama praktyka Kościoła oparta na umartwianiu duszy i nakazie ascezy mierziła obu filozofów w takim samym stopniu.

Z drugiej strony sama biografia Nietzschego mogłaby się okazać dla Zdziechowskiego cennym materiałem do rozważań. W końcu niemiecki filozof był synem pastora, od którego rodzina wymagała, aby poszedł w ślady ojca, badaczem, który dogłębnie studiował Biblię i znał doktrynę chrześcijańską. Wileński profesor rozważał problem odwrócenia się inteligencji od Kościoła, więc niemiecki myśliciel okazałby się doskonałym przykładem tego, jak Kościół opuszczają ludzie inteligentni, którzy czują się zranieni i zaszczuci jego skostniałą doktryną. Polski filozof miałby więc cenny materiał do badań zarówno w sferze tego, jak zachodzi ten proces, ale i jak przekłada się na dzieła atakujące Kościół, często po linii krytyki, jakiej sam Zdziechowski dokonywał.

\footnotetext{
${ }^{42}$ F. Nietzsche, Antychryst, tłum. L. Staff, Zielona Sowa, Kraków 2005.

${ }^{43}$ M. Żelazny, Nietzsche, s. 131.

${ }^{44}$ M. Zdziechowski, Kościół a inteligencja, [w:] tenże, Wbór pism, s. 167.

${ }^{45}$ F. Nietzsche, Antychryst, s. 36; fr. 3.
} 
A nt y s e mity zm. Do najważniejszych myśli zawartych w filozofii Nietzschego, które mogłyby głęboko zainteresować Mariana Zdziechowskiego, należą trzy wyżej opisane. Krytyka nacjonalizmu i militaryzmu niemieckiego, gdyż pozostają w relacji z rozwojem tak nienawidzonego przez niego bolszewizmu, krytyka praktyk Kościoła, gdyż wileński profesor sam walczył o potrzebne w nim reformy, jak i zagadnienie pesymizmu, tak ważne w jego myśli, a z którym Nietzsche radził sobie we właściwy dla siebie sposób. Są to wątki najważniejsze, ale nie wątki jedyne, gdyż szukać można także kwestii pomniejszych. Z pewnością należeć do nich będzie problem narodu żydowskiego. Koncepcje obu omawianych tutaj myślicieli zawierają istotne podobieństwa, dzięki którym pojawia się kolejna płaszczyzna porozumienia, kolejne motywy myśli Nietzschego, które mógłby Zdziechowski wykorzystać dla swoich teorii.

Obaj filozofowie przez swoje pisma narazić się mogli na zarzut antysemityzmu. Pomińmy tutaj problem dokładnego zdefiniowania na czym miałby w ogóle antysemityzm polegać. Rozważania natury semantycznej wymuszałyby na nas dokładniejsze opisanie problemu i kierowałyby nasze badania na inną drogę.

Zdziechowski mógłby dzisiaj uchodzić za antysemitę, a to ze względu na specyfikę swojego spojrzenia na naród żydowski ${ }^{46}$. Sam powtarzał, że nie żywi do niego żadnych wrogich uczuć (resentymentu, jakby z pewnością powiedział Nietzsche). Analizując zagadnienie wewnętrznych problemów II Rzeczypospolitej, zwracał przede wszystkim uwagę na kwestię mniejszości narodowych, którym przez kilkaset lat daliśmy powód do żywienia do nas nienawiści. Winniśmy więc w stosunku do nich iść na wszelkie ustępstwa, nawet naszym kosztem. Polonizacja byłaby braniem złego przykładu z państw nacjonalistycznych, zresztą i tak nie mielibyśmy dość siły na jej przeprowadzenie. Podziwiał przy tym cnoty mniejszości żydowskiej, jej skrzętność i zapobiegliwość, gospodarność i rodzinność, które powinny wzbudzać zazdrość i być wzorem dla innych narodów ${ }^{47}$.

Ale także uważał, że z samej historii ich obecności w Europie należy wysnuć wniosek, że cała nasza kultura jest dla nich nie tylko czymś obcym, ale i wrogim, zatem zawsze stają po stronie każdej rewolucji, co widać dobrze w rewolucji bolszewickiej, do której doprowadzili wraz ze swoim „figurantem

\footnotetext{
${ }^{46}$ M. N. Jakubowski, Ciagłość historii, s. 235 (przypis 42).

${ }^{47}$ M. Zdziechowski, Wojciech Dzieduszycki, [w:] tenże, Europa, Rosja, Azja, s. 26.
} 
Leninem"48. Przepędzani i pozostający w pogardzie, bici i ciemiężeni, musieli Żydzi stać się czymś naszej cywilizacji wrogim, tym, co stanowi czynnik jej zniszczenia. Cierpliwość i pokora tego narodu zawiodła ich ostatecznie na wszystkie ważne stanowiska, otworzyła drogę do każdej dziedziny życia politycznego i społecznego, zatem jasne jest, że cały kontynent musiał się stać ich legendarną ziemią obiecaną. Trudno byłoby więc nie zgodzić się z Jakubowskim, że głosząc takie poglądy, Zdziechowski uznany by dziś został za antysemitę. Należy tu wspomnieć o roli, jaką według Zdziechowskiego w całej rewolucji odegrali Żydzi. Skoro bowiem cały świat chrześcijański jest dla nich czymś obcym, skoro zawsze stają po stronie każdej rewolucji, to dziwić nie powinno, że wsparli także rewolucję bolszewicką, której celem nie jest nic innego, niż totalna zagłada wrogiej im kultury ${ }^{49}$. W jednym ze swoich tekstów rzuci Zdziechowski mimochodem, że rewolucja bolszewicka nie jest wcale rewolucją rosyjską, bo stoją za nią Łotysze, Żydzi i Polacy.

Pierwiastek żydowski jest więc pierwiastkiem niszczycielskim, stoi po stronie każdej rewolucji i optuje za każdą zmianą, dzięki której zwiększy swoją władzę i pomności ilość posiadanych dóbr i wpływów. Referując poglądy Dzieduszyckiego, zgadza się z nim Zdziechowski, że nawet jeżeli idea bolszewizmu i nacjonalizmu wyczerpie się w końcu nie przynosząc naszej kulturze zagłady, to przyszłość wcale nie rysuje się optymistycznie. Ostatecznie zwyciężyć musi „wielki kapitał”, osławiony „lewiatan naszych czasów”, którego znamieniem jest „coraz większa koncentracja potęgi kapitału w rękach nielicznych szczęśliwców, miliarderów" ${ }^{50}$. Oczywiście największymi przemysłowcami i posiadaczami największej ilości dóbr będą w tej wizji Żydzi, cały świat zaś stanie się ich przepowiedzianą ziemię obiecaną.

Zawarte w filozofii wileńskiego profesora motywy tego rodzaju słusznie rażą czytelnika, powodując tym samym uczucie niesmaku. Zapewne nie zauważył on, jak sam poddaje się propagandzie nacjonalistycznej, zwalczającej mniejszości narodowe, w Żydach szukającej pierwiastka niosącego zniszczenie. Mogłoby się więc wydawać, że wiele dla potrzeb takiej, mówiąc wprost, rasistowskiej interpretacji mógłby wyczytać w dziełach Nietzschego. Należy tutaj jednak poczynić istotne spostrzeżenie. Zarzut antysemityzmu w stosunku do niemieckiego filozofa okazuje się nietrafiony, o czym mówi jego

\footnotetext{
48 Tamże, s. 19.

${ }^{49}$ Zob. chociażby teksty Zdziechowskiego: Mickiewicz, Miereżkowski i rewolucja rosyjska, s. 243, czy: Idea polska na kresach, s. 22.

${ }^{50}$ M. Zdziechowski, Wojciech Dzieduszycki, s. 24.
} 
serdeczny przyjaciel, Fanz Overbeck. Informuje nas, że antysemityzm budził zarówno w nim, jak i w młodszym odeń przyjacielu poczucie głębokiego niesmaku, był zagadnieniem, o którym rozmawiali rzadko, nigdy z pasją, a zazwyczaj panowała między nimi milcząca zgoda co do tego, że należy go bezwzględnie potępićs1.

Ale też w pismach Nietzschego znajdują się fragmenty, które mogły służyć antysemitom, które mogli wykorzystać na rzecz budowania chorej doktryny nienawiści rasowej. Podkreślając głęboki sprzeciw Nietzschego względem antysemityzmu, zauważał Overbeck, że czynione przez niego analizy miały nie antysemicki, lecz antychrześcijański charakter, że chodziło mu o wskazanie szkodliwej dla człowieka moralności, którą chrześcijaństwo przejęło od Izraelitów ${ }^{52}$.

Zauważał Nietzsche słuszność słów Tacyta, że Żydzi są narodem stworzonym do niedoli, że ich religia skonstruowana jest tak, aby znosić cierpienie i niesprawiedliwości losu ${ }^{53}$. Dzisiaj należy uznać, że świadczy to o ich moralnej sile, dowodem tego zaś jest ich postawa podczas holocaustu, a zwłaszcza ich moralne zwycięstwo nad nim. Ale Nietzsche był innego zdania, uważał, że jest to moralność, która upadla człowieka, która chrześcijaństwu dawała wymierne korzyści, bo pozwalała podporządkowywać sobie kolejne narody, Żydom zaś dwa razy niemal pozwoliła zapanować nad znaną częścią świata. Pierwszy raz podczas niewoli egipskiej, gdzie faraon musiał podjąć drastyczne kroki, aby władza nie przeszła w ich ręce, natomiast drugi przykład zdarzył się prawdopodobnie w czasach Nietzschemu i Zdziechowskiemu współczesnych.

Niemiecki filozof w książce $Z$ genealogii moralności obarczał odpowiedzialnością za całkowitą zamianę wartości dostojnych na wartości motłochu także Żydów. U początku rasy ludzkiej emotywne, władcze jednostki decydowały co nazwane będzie „dobrym”, a co „lichym”. Był to okres, gdy nikt nie miał złudzeń, że wartości te nie są absolutne i nie mają boskiego pochodzenia. Dopiero gdy niższe jednostki w hierarchii doszły do głosu, doszło do zamiany miejscami wszystkich wartości. Co do tej pory było „lichym”, stało

${ }^{51}$ F. Overbeck, Nietzsche. Zapiski przyjaciela, tłum. T. Zatorski, Wyd. słowo/obraz terytoria, Gdańsk 2008, s. 8.

${ }^{52}$ Tamże, s. 29.

${ }^{53}$ F. Nietzsche, Poza dobrem i złem, tłum. S. Wyrzykowski, Nakład Mortkowicza, Warszawa 1907, fr. 194. 
się „dobrym, dobre” zaś poczęło uchodzić za „złe”. To było nieuniknione, skoro bezrozumny, rządzony resentymentami motłoch sięgnął po władzę ${ }^{54}$.

Nie nazywamy poglądów Nietzschego antysemickimi z zasadniczego powodu. Antysemityzm potępiał, sam zaś należał do pierwszych antropologów, którzy chcieli badać różne nacje. Pomijamy tutaj krytykę, z jaką spotkała się jego teza o genealogii moralności, bo nie o jej niesłuszność chodzi, lecz o fakt, że nie była ona podszyta nienawiścią rasową do Żydów, a jedynie chłodną analizą rozwoju moralności w kulturze europejskiej. Dodajmy, że wśród przyjaciół Nietzschego były także osoby pochodzenia semickiego, by wspomnieć chociażby Paula Ree.

Zdziechowski mógłby więc, po bliższym zapoznaniu się z pismami Nietzschego, znaleźć, po pierwsze, przykłady krytyki narodu żydowskiego, po drugie, wzór krytyki natury antropologicznej, nie zaś nienawiści rasowej, którą również się brzydził, ale którą - jak wykazaliśmy - również w paru momentach sam przejawiał. Sprawiłoby to zapewne, że jego podejście do mniejszości żydowskiej nie byłyby może aż tak jednostronne, w końcu teza, że Żydzi są jedynie rewolucjonistami czyhającymi na rewolucję, która utopi świat w morzu krwi jest dla tej nacji krzywdząca i musi budzić stanowczy i zaciekły sprzeciw, jeżeli zaś znajdowały się między nimi i takie jednostki, to z pewnością generalizacja taka aż razi swoją jednostronnością. Można się też zastanowić, czy gdyby Zdziechowski wliczył się w poczet czytelników i komentatorów Nietzschego, to czy swoim zajmującym i lekko prowadzonym piórem (po zignorowaniu barwnego i nieraz brutalnego sposobu wyrażania się Nietzschego) nie przysłużyłby się temu, że niemiecki filozof nie miałby tak złej sławy po drugiej wojnie światowej i łatwiej byłoby dokonać demitologizacji jego doktryny, wykazywać niesłuszność antysemickich interpretacji nietzscheanizmu. Czy jednak Zdziechowski złagodziłby swoją krytykę mniejszości żydowskiej pod wpływem Nietzschego i czy sam Nietzsche nie byłby przez to interpretowany jako antysemita, tego stwierdzić nie możemy, bo Zdziechowski szansy nie wykorzystał.

Opisane powyżej idee z myśli Nietzschego wskazują jednoznacznie, jak niesłuszna była jego ignorancja względem niemieckiego filozofa. Wspomnijmy w końcu, że szeroka spuścizna pisarska wileńskiego profesora składa się przede wszystkim z relacji z przeczytanych książek, lub z zestawienia poglądów różnych myślicieli. $W$ tekstach tych Nietzsche występuje $\mathrm{z}$ rzadka, nigdy

${ }^{54}$ F. Nietzsche, Z genealogii moralności, tłum. L. Staff, Zielona Sowa, Kraków 2003, Rozprawa I. 
zaś nie poświęcono mu więcej uwagi. Tak wyśmienity literaturoznawca i filozof, jakim był Zdziechowski, mógłby w filozofii Nietzschego znaleźć wiele argumentów i cennych idei dla własnych poglądów. Niestety automatycznie zdyskredytował niemieckiego myśliciela.

\section{Bibliografia}

Chocimski Z., Przedmowa, [w:] M. Zdziechowski, Widmo przyszłości, Stowarzyszenie Kulturalne Fronda, Warszawa 1999.

Gomez T., Fryderyk Nietzsche, tłum. T. Ostrowski, Muza S.A., Warszawa 2007.

Jakubowski M. N., Ciagłość historii i historia ciagłości. Polska filozofia dziejów, UMK, Toruń 2004.

Kotłowski T., Niemcy, dzieje państwa i społeczeństwa 1890-1945, Avalon, Kraków 2008.

Marciniak M., Inspiracje Schopenhauerowskie w filozofii zła Mariana Zdziechowskiego, „Studia z Historii Filozofii”, 1(4)/2013.

Nietzsche F., Antychryst, tłum. L. Staff, Zielona Sowa, Kraków 2005.

Nietzsche F., Ecce Homo, tłum. L. Staff, Zielona Sowa, Kraków 2003.

Nietzsche F., Jutrzenka, tłum. L. M. Kalinowski, Zielona Sowa, Kraków 2006.

Nietzsche F., Ludzkie, arcyludzkie, tłum. K. Drzewiecki, Zielona Sowa, Kraków 2006.

Nietzsche F., Niewczesne rozważania, tłum. L. Staff, Zielona Sowa, Kraków 2003.

Nietzsche F., Poza dobrem i złem, tłum. S. Wyrzykowski, Nakład Mortkowicza, Warszawa 1907.

Nietzsche F., Wiedza radosna, tłum. L. Staff, Zielona Sowa, Kraków 2006.

Nietzsche F., Z genealogii moralności, tłum. L. Staff, Zielona Sowa, Kraków 2003.

Nietzsche F., Zmierzch bożyszcz, tłum. P. Pieniążek, Zielona Sowa, Kraków 2004.

Overbeck F., Nietzsche. Zapiski przyjaciela, tłum. T. Zatorski, Wyd. słowo/obraz terytoria, Gdańsk 2008.

Sikora A., Towiański: rewelacja i spetnienie, [w:] tenże, Posłannicy słowa. Hoene-Wroński, Towiański, Mickiewicz, PWN, Warszawa 1967.

Stomma S., Stowo wstępne, [w:] M. Zdziechowski, O okrucieństwie, Znak, Kraków 1993.

Zaczyński M., Rozdźwięk okropny w pięknie świata, czyli homo crudelis, [w:] M. Zdziechowski, O okrucieństwie, Znak, Kraków 1993.

Zdziechowski M., Europa, Rosja, Azja. Szkice społeczno-literackie, Antyk, Komorów 2007.

Zdziechowski M., O okrucieństwie, Znak, Kraków 1993. 
Zdziechowski M., Widmo przyszłości, Stowarzyszenie Kulturalne Fronda, Warszawa 1999.

Zdziechowski M., Wybór pism, Znak, Kraków 1993.

Żelazny M., Nietzsche, „ten wielki wzgardziciel”, WN UMK, Toruń 2007.

Żelazny M., Wpływ Schopenhauera i Wagnera na twórczość młodego Nietzschego, „Studia Filozoficzne”, nr 9 (180), 1981.

\section{Abstract}

\section{About Zdziechowski's Unjust Reluctance of Nietzsche}

This text refers to the reluctance Polish philosopher, Marian Zdziechowski, to the philosophy of Friedrich Nietzsche. Zdziechowski ignored Nietzsche's achievements, thoughthim to be overtly harmful. The text argues that if he paid a little more attention to the thought of German philosopher, he could noticed a lot of valuable thoughts to yourself. These are mainly: criticism of German society, pessimism as a starting point in reflections, the criticism of the Church, as well as analysis of the Jewish people.

Key words: Nietzsche, Zdziechowski, pessimism, criticism of the Christian religion, anti-Semitism, criticism of pangermanism 